\title{
A deposit of Kilwa-Type Coins from Songo Mnara, Tanzania
}

\author{
Authors: John Perkins*, University of Bristol and Flinders University \\ (john.perkins@flinders.edu.au) \\ Jeffrey Fleisher, Rice University (jfleisher@ rice.edu) \\ Stephanie Wynne-Jones, University of York (stephanie.wynne-jones@ york.ac.uk) \\ $*=$ Corresponding author
}

\begin{abstract}
A deposit of coins was recovered during excavations at Songo Mnara, Tanzania, containing over 300 copper Kilwa-type coins. This is the first deposit or hoard of these coins found in a welldefined archaeological context, and it therefore offers a unique glimpse into both the typology of these coins and their contemporary uses. In this paper, the ramifications of the Songo Mnara deposit are discussed. In particular, the deposit is firmly attributable to the end of the $14^{\text {th }}$ or very early $15^{\text {th }}$ century, allowing for some chronological resolution. Coins of the late $11^{\text {th }}$ to early $12^{\text {th }}$ -century sultan Ali ibn al-Hasan show that these types remained in circulation for many centuries. In addition, the common coin type of Nasir ad-Dunya can now be attributed firmly to the $15^{\text {th }}$ and possibly $14^{\text {th }}$ centuries by this find. Finally, this paper discusses the burial of the coins in the foundations of a stonehouse, and the fact that this likely represented the building of value into the house and an investment in place. Other finds, such as a carnelian necklace found with the coins, testify to the importance of this practice.
\end{abstract}

Keywords: Swahili; Kilwa: Songo Mnara; coins; hoard; deposit 
A Hoard of Kilwa-type coins 2 


\section{Introduction}

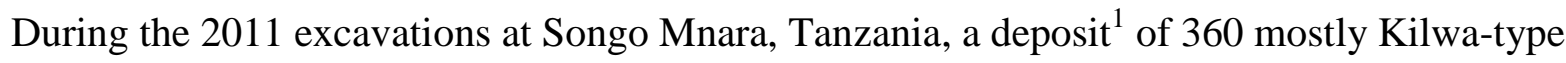
coins and 15 carnelian beads was found below the plaster floor of a $14^{\text {th }}-15^{\text {th }}$ - century stonehouse. The Songo Mnara coin deposit is one of only three excavated hoards found on the eastern African Swahili coast. It is unique in that it comes from a well-stratified context, and that it dates to the mid-second millennium $\mathrm{AD}$, a period from which no other hoards have been located. The coins are virtually all Kilwa-type, meaning here coins associated with and likely minted at or around Kilwa (following Walker 1936, although some of the coins he identified are now believed to have come from Zanzibar). These were recorded primarily from excavations at Kilwa (Chittick 1973, 1974; Freeman-Grenville 1957, 1958) and Songo Mnara (Fleisher and Wynne-Jones 2010).

Here, we describe the coin deposit and its context, situate it among other coin finds at Songo Mnara (Fleisher and Wynne-Jones 2010; Wynne-Jones and Fleisher 2012), and compare it to Swahili numismatic understandings and to other hoards found at coastal sites. Finally, we reflect on the importance of the deposit, for its chronological and numismatic implications, and for the possible contextual meanings of its location.

\section{Songo Mnara and the Kilwa archipelago}

\footnotetext{
${ }^{1}$ We speak here of deposit rather than hoard, as it seems unlikely that the coins and the carnelian beads which accompanied them were intended for retrieval. They were covered by a thick plaster floor. Yet, the composition differs little from the known hoards of the Swahili Coast. The terms hoard and deposit might therefore be seen as somewhat interchangeable in this context.
} 
Songo Mnara is a grand Swahili stonetown, located on Songo Mnara Island in the Kilwa archipelago (Figure 1). Historically, Songo Mnara has remained in the shadow of its more prominent neighbour, Kilwa Kisiwani, which sits on the northwest corner of the island to its north. Kilwa Kisiwani was an important stonetown, with occupation dating back as far as the $8^{\text {th }}$ century AD (and perhaps further, see Chami 2006); it rose to prominence from the $11^{\text {th }}$ century onwards, reflected in the construction of an elaborate townscape with some of the grandest structures built on the precolonial coast. The inhabitants were important merchants in the Indian Ocean world, and traded with partners in the Persian Gulf, Red Sea, and onwards as far as China. Excavations throughout the 1960s (Chittick 1974) recovered a rich record of settlement through to the arrival of the Portuguese in the $16^{\text {th }}$ century, as well as a revival of fortunes during the $18^{\text {th }}$ century. This was understood with reference to external histories, as well as the Kilwa Chronicles, two uniquely-detailed indigenous histories of the town, transcribed first by the Portuguese from its traditional oral version. The Chronicles recount the dynastic succession of a series of Shirazi and later Mahdali sultans, along with biographical detail on some. It is now unusual to regard these chronicles as a literal history (cf. Chittick 1965, Pradines 2009) and they tend to be seen as an imaginative retelling of the history of Kilwa, emphasizing certain aspects that were deemed important to later townspeople, such as the Shirazi roots of the elite classes (Horton and Middleton 2000). Nonetheless, the chronicles do offer a framework by which to begin exploring the coins of Kilwa, which are a striking feature of the archaeology here.

The minting of coins is known elsewhere on the Swahili coast, notably with some early issues at Shanga (Horton 1996) and a possible series from the $11^{\text {th }}-15^{\text {th }}$ century town of Tumbatu on Zanzibar (Horton, forthcoming). Yet Kilwa was the most prolific minter of coins, with issues known of gold (Brown 1991), silver (Horton et. al. 1986) and copper (Walker 1936, 1939 and 
Freeman-Grenville 1957). As discussed below, the majority of these coins have been recovered from chance finds, and collections. It seems that the copper coins circulated as a form of currency in the region of Kilwa influence, which included Kilwa itself, Songo Mnara, and Kisimani Mafia (Fleisher and Wynne-Jones 2011). The sheer numbers of these coins, as well as the range of uses that they had, suggest that they should not be regarded as petty change (cf Middleton 2003), but as a key part of the local exchange and ritual economies of these sites, even though they did not seem to filter into Indian Ocean markets (Wynne-Jones and Fleisher 2012).

Unlike the extensive and long-lived settlement of Kilwa Kisiwani, Songo Mnara is a compact, 6-ha, coral-built town constructed in the late $14^{\text {th }}$ or early $15^{\text {th }}$ century, and then inhabited until the early $16^{\text {th }}$ century at the latest (Garlake 1966, Mathew 1959). The relationship of this site to Kilwa Kisiwani is not well understood, and may be beyond the reach of archaeology, yet it is clear that it was part of cultural developments in the archipelago that included the growth of the town of Kilwa. Songo Mnara was constructed over a short period of time, with no evidence for settlement before the late $14^{\text {th }}$ century, and then an intense period of building activity. The remains of more than forty houses, six mosques, and hundreds of graves and tombs are well-preserved, and seem to have been built during a short period of activity, perhaps as little as 20 years. This period coincides with the 'golden age' of trade at Kilwa, when grand houses were being added to the townscape there too; Songo Mnara might therefore be seen as part of this general boom, but was a functioning settlement in its own right. The Songo Mnara Urban Landscape Project has been exploring the site since 2009, building a robust picture of daily life across the town, with excavations in both houses and open spaces (Wynne-Jones and Fleisher 2010, 2011). This project is exploring uses of space within the town (Fleisher and Wynne-Jones 2012) and is therefore placing great emphasis on context. 


\section{The archaeological context}

Excavations at Songo Mnara in 2009 and 2011 (and previous excavations by Pradines; Pradines and Blanchard 2005) have therefore revealed shallow deposits at the site reflecting occupation over only a comparatively short period, perhaps $100-150$ years. These excavations have also demonstrated the integrity of the archaeological deposits, with many intact contexts above and below house floors, as well as undisturbed artifact spreads in open spaces. In 2009, a complete house was excavated (House 44 on map, following Garlake 1966) and this demonstrated the possibilities of exploring spatial contexts in an ancient Swahili house; numerous deposits of ceramics and beads remained on the plaster floor of rooms. The back room had a dirt floor and yielded a rich assemblage of artifacts related to cooking and production (Wynne-Jones 2013). Excavation of this room revealed a sequence that was to become a standard pattern for the site. Beneath the floors of Songo Mnara's houses are a series of fills, brought in to the site from surrounding areas. They vary by structure, but in House 44 were primarily beach sands, deposited in a series of layers relating to the construction and occupation of the house. The back room of House 44 had been a hive of domestic activity with a rich midden built up over time. At one point, this had been covered over with another layer of fill and a second floor level added. Within this rich record of 100 years of occupation, an assemblage of 36 coins was spread throughout the sandy fill of the floor deposit (Fleisher and Wynne-Jones 2010).

The deposit reported here is from another back room, this time of House 31 (Figure 2), excavated to test ideas about differences between deposits from front and back rooms in houses, and augment the results from House 44. This room, in the southeast corner of the house, was $2.25 \times 4.0 \mathrm{~m}$ in size. After excavating the fallen rubble, contexts above the floor were carefully 
mapped and removed; 8 coins were found in these. The plaster floor was supported by a compact layer of coral rubble (\#17009) atop a sandy fill (\#17013). These surrounded a plaster sump structure (\#17014), capped by a sandstone slab, which extended into the eastern wall of the room, draining in that direction. As elsewhere, the floor was underlain by sandy foundation fills. Although colour differences are evident within these, often recorded as different contexts, it is impossible to pull these apart into a chronological sequence. As described by Garlake (1966) the cleared areas were often used as platforms for lime burning, coral carving etc., and this results in a range of lenses which do not correspond to the walls of the room above. The fills are both complex and simple: overall, we can see the sandy deposits as being laid down over a fairly short period of construction. It is within these that the two buried deposits reported here were found. The first was a buried deposit containing 360 mostly Kilwa-type coins, 11 carnelian beads, and 2 glass beads (Figures 3 and 4; \#17011 and \#17012) placed into the floor fills in the northwestern corner of the room, to the west of the door. Another deposit against the southern wall (\#17010 and \#17016) contained quantities of pottery and two carnelian beads but no coins. These can both be seen as deliberate deposits, placed into excavated pits in the under-floor sandy fills. Due to the nature of the deposits themselves - loose among the sand - and the surrounding contexts, it is not possible to reconstruct the form of the deposition, but as it was part of the laying down of foundations, we should assume these were single collections, placed together into a pit in the sand. They fit into a pattern of foundational deposits across the site more generally (WynneJones 2013). Otherwise, the floor fills contained low quantities of artifacts. The basal layers consisted of a layer of porites chips (\#17017), related to the finishing of porites door jambs, above the sterile sand that constitutes the natural subsoil; this context also contained 3 coins and 2 carnelian beads, likely associated with the deposits in \#17011 and \#17012. 
The majority of the coins were located clustered together, along with the carnelian beads, in a rectangular area measuring $30 \times 30 \mathrm{~cm}$. All fill was sieved through a $2 \mathrm{~mm}$ mesh, retrieving additional beads and coins from the surrounding sand. Thus, the coins were sealed beneath the mortared floor and it is unlikely that they were meant to be retrieved. No other directly dateable material was found within either of the two contexts, but local and imported pottery within the floor fills suggests that the house was built some time during the late $14^{\text {th }}$ or early $15^{\text {th }}$ century. Although it is possible that the coins and beads were once deposited in some perishable container, the spread of the coins and beads suggest that no container was used (unlike other hoards found in cloth pouches and ceramic jars, see Horton et al. 1986; Chittick 1965).

\section{Previously-located coins from Songo Mnara and Eastern African Coin Hoards}

In total, 567 coins have been found from Songo Mnara: 64 from the 2009 season (Fleisher and Wynne-Jones 2010), 485 from the 2011 season (including the deposit discussed here, Fleisher and Wynne-Jones 2013), and 18 coins recently recovered from storage at the British Institute in Eastern Africa (Perkins 2012). The latter 18 coins were unpublished but likely recovered by Chittick during informal excavations at Songo Mnara in the 1960s (Chittick 1961). The coins from the 2009 excavations are fully published and discussed elsewhere (Fleisher and Wynne-Jones 2010; Wynne-Jones and Fleisher 2012). These coins and all those from 2011 come from stratified contexts across the site.

Although researchers have reported coin hoards from eastern Africa (Walker 1936, 1939; Freeman-Grenville 1957), most of these have no associated stratigraphic context, and many appear to be simply groups of coins gathered by collectors rather than having been deposited together in the past (Chittick 1967: 195). Some of these collections do probably represent hoards, 
such as the collection of 99 coins from Mtandura (Chittick 1967) said to be found in the course of digging a well (and purchased by Chittick). However, only two other hoards have been properly excavated previously: one from Mtambwe Mkuu on Pemba Island which contained 2,087 silver and 13 gold coins (Horton et al. 1986; Horton, forthcoming) and one from Kisimani Mafia on Mafia Island, which included 570 copper coins (Chittick 1965: 285).

The Mtambwe Mkuu hoard has been an important aid to establishing the early chronology and development of coinage on the Swahili Coast. While the depositing of the Mtambwe Mkuu hoard has a terminus post quem of 1066 from a dated Fatimid gold coin contained in it, the dates of possible deposition are still wide and there is no indication of when the local coinage contained in it began. Despite the fact that it did not contain a single copper coin, it establishes a clear link to the copper coinage of Kilwa; virtually identical designs were used on the silver coins of Ali ibn al-Hasan found in the Mtambwe Hoard and those of copper of the same ruler found in large numbers in later deposits in the Kilwa archipelago, including the Ali ibn al-Hasan Type B (new typological names based on Perkins in prep., formerly Walker XIII and XIV, Walker 1936).

The Kisimani Mafia Hoard, excavated by Chittick in 1964 (Chittick 1965), included 570 copper Ali ibn al-Hasan Type A coins, (previously Walker type XII, Walker 1936). It is difficult to date the Kisimani Mafia Hoard as the context of its discovery was never fully published, except that Chittick (1965: 285) noted that it was found "buried in a pot against the wall of a mosque." The matter at Mafia is further complicated by the loose stratigraphies and chronology presented by Chittick’s excavation publications (Freeman-Grenville 1971).

\section{The Songo Mnara Deposit and Implications}


Of the 360 coins from the Songo Mnara deposit (Table 1), all of which are copper, 102 (28\%) could not be attributed; of these, 34 were totally unidentifiable, with 68 of uncertain Kilwa-type. Among the remaining 258 coins, 5 are from foreign Islamic locations: three from Mogadishu (including one Muhammad l'Adil coin, formerly believed to be a Kilwa-type coin, see Freeman-Grenville 1963), and two unattributed foreign Islamic coins, possibly from the Arabian peninsula. Even though these coins are well-preserved, Islamic copper coins from the Arabian peninsula are relatively unknown and only sparsely published; Album (1999) is one of the few reference works. Of the Kilwa-type coins, eleven have only the name or patronym legible, with not enough text surviving on the obverse and reverse to be able to assign them safely to relevant rulers. The assemblage includes 7 of the 8 known Kilwa-type coins, including those of Nasir ad-Dunya type and missing only those of al-Hasan ibn Talut. The proportions of identifiable coins are listed in Table 1.

\section{Chronological Issues}

Songo Mnara was occupied for such a short period, thus there is only a small window for the placing of the deposit: approximately 50 years between the end of the $14^{\text {th }}$ and beginning of the $15^{\text {th }}$ century AD. This is a much narrower and more secure date range than afforded any other coin hoards found on the eastern African coast. The relatively late date of deposition of the coins means that the Songo Mnara deposit cannot give us answers regarding the early development of the copper coinage; however, it does confirm some ideas about Kilwa-type coins as dating tools, offer new information on the types of coins that were in circulation in these centuries and help resolve the dating of one particular type, the Nasir ad-Dunya coins. 
As already indicated by the first season's coins at Songo Mnara (Fleisher and WynneJones 2010), the evidence from the deposit finally confirms Chittick's (1974) assumption that it is only the absence, not presence, of certain coin types that can give any indication of dates. The uncertainty surrounding the dates of many of these coins means that currently they cannot be used to date archaeological strata; even with a clearer sense of when certain types were first produced, their long use-lives will always make their usefulness for dating limited at best.

One of the most significant aspects of this deposit regards the dating of the coins of the Nasir ad-Dunya type, which constitute a large portion of the coins. Chittick (1974) argued on the basis of his excavations at Kilwa that these coins probably dated from the $16^{\text {th }}$ century (see also Mitchell 1970). More recently it had become clear (Fleisher and Wynne-Jones 2010) that a date in the $15^{\text {th }}$ century at the latest had to be considered due to the numbers found at Songo Mnara. The Songo Mnara deposit possibly pushes this terminus ante quem further back, as they were present in large quantities, of which many were already worn. A minting date before the early $15^{\text {th }}$ century now seems beyond doubt and, considering their quantity and their wear in the deposit, the mid to late $14^{\text {th }}$ century seems a distinct possibility. Additionally, the Nasir adDunya coins from this deposit also call into question Album's (1999) theory that they were copies of those of the Rasulid ruler al-Nasir Ahmad. We are unaware of any coins of this ruler that would match the Nasir ad-Dunya coins in appearance, and the date of al-Nasir Ahmad's reign in the first quarter of the $15^{\text {th }}$ century makes the likelihood of his coins having served as the prototypes even more remote. Finally, these finds also question the suggestion that these coins are anonymous copies of coins (Mitchell 1970), as generally assumed. They may instead bear the name of a heretofore unknown ruler of Kilwa. The poor quality and - in many cases - illegibility of the coins could be attributed to a lack of skilled die cutters. In fact, standardisation in minting 
has become clear from results of X-Ray Fluorescence (XRF) analysis (Perkins in prep.). This allows us to view the elemental make-up of the copper alloys, and the average copper content of the 21 coins tested lies at $97.28 \%$ with a standard deviation of only 1.26 . This suggests that they were meant as more than simple tokens or imitations, but were purposefully minted according to a set pattern and process.

A further important aspect is that, apart from the al-Hasan ibn Talut coins, all known Kilwa rulers are represented in the deposit. It demonstrates that all these coin types were still in circulation or at least available at the time when the deposit was made in the late $14^{\text {th }}$ to early $15^{\text {th }}$ century. However, the considerable portion of the Ali ibn al-Hasan coins in this deposit requires some further deliberation. The two types of Ali ibn al-Hasan coins (A and B) are considered together; due to strong stylistic similarities and identical legends it is relatively sure that they were issued by the same person and not two different people of that name. Coins with this legend form c. $10 \%$ of the deposit, mirroring assemblages known elsewhere, across the site of Songo Mnara and at Kilwa itself (Table 2). Two of the authors have previously suggested that this might be due to immobilisation: the continued minting of $11^{\text {th }}$ - century types into later years (Fleisher and Wynne-Jones 2010). Yet, the coins in this deposit are generally much more worn than the other coins contained in it, with the possible exception of the Da'ud ibn al-Hasan coins, suggesting that they were in circulation for a longer period than the others. Further, it seems likely that one of the coins from the deposit was struck by the same die as one of the coins found in Chittick's Mafia hoard (Figure 5). It would thus appear that the copper coins of the Swahili Coast were in fact minted at certain points in time, with these coins being the earliest. This seems further confirmed by the relatively homogenous metal content of the Ali ibn al-Hasan coins, as shown by the XRF results (Perkins in prep.). Their continued appearance in later centuries might 
then be related to the quantities that were minted during the life of a Sultan and supports Freeman-Grenville's (1971) assertion that no coin type was ever withdrawn.

If we compare the assemblages of the Songo Mnara deposit to the other site finds and other assemblages of coins then it becomes apparent that they are representative of the Kilwatype copper coins found on the Swahili Coast (per Fleisher and Wynne-Jones 2010). It also confirms that no new types were issued prior to the arrival of the Portuguese and suggests that they were still in circulation when the Portuguese sacked Kilwa in 1505. It must have been these coins that were described by Hans Mayer in his eyewitness account of Kilwa in that year (Freeman-Grenville 1962, pp. 80-112).

\section{Quantities}

One striking aspect of the collection of coins from Songo Mnara is the quantity located to date $(n=567)$. The total number of coins from the large scale excavations at Kilwa was only c. 1900, excluding surface finds, from areas of excavations that far exceed those at Songo Mnara. Excavation techniques clearly play a large part in this, as all the deposits from Songo Mnara have been sieved through either 2 or $4 \mathrm{~mm}$ mesh (cf. Pradines and Blanchard 2005), while very few of the Kilwa deposits were sieved at all. This suggests that the quantities of coins that were in circulation in the Kilwa region have been underrepresented by the amounts reported by Chittick. This was a coinage system with thousands of coins in circulation, and the data from Songo Mnara represent the first idea of how extensive the minting process was in the archipelago.

\section{Preservation}


As discussed, ratios of different rulers present in the coin deposit closely approximate those in the larger assemblage (Table 2), and the deposit thus likely represents a random collection of coins at the time of deposition, rather than a selection of particular rulers, coin qualities or other attributes. There are some differences found in the quantities of coins in the deposit and larger assemblage: the deposit contained many fewer unidentifiable coins compared to the site assemblage (9.4\% deposit, $30.4 \%$ site); the deposit contained more coins that contained some identifying information but could not be assigned to a particular ruler (18.9\% of the deposit, 5.8\% site assemblage). These differences suggest that the deposit coins have an overall better state of preservation in comparison to general site finds. This is due, in part, to the protection afforded the coins as a deposit and their removal from circulation. A further reason might be the original state of preservation at the time of deposit/loss, with only well-preserved coins being deposited, as opposed to a more random sample of preservation being lost across the site.

\section{Copper coins and relative value}

The Songo Mnara deposit speaks to debates about the relative value of Kilwa's copper coinage, especially the comparison between copper, silver and gold issues (Wynne-Jones and Fleisher 2012; Horton and Middleton 2000). Middleton (2003:516) has argued that copper coins were used as coastal currency "in petty exchanges between unrelated sellers and buyers." In contrast, he suggests that gold and silver coins were not used as currency, but rather as "counters, vouchers or tokens of value" (2003:515) and were often saved and secreted away rather than exchanged more broadly. The Songo Mnara deposit challenges this interpretation, in that copper coins were collected and stored in a manner that Middleton expected only of gold and silver issues. In this instance, copper coins were valuable enough to be taken out of circulation and 
deposited with other rare and likely high value items, a string of finely-made carnelian beads, suggesting that copper coins had a greater value than suggested by Middleton. However, we are not arguing that they were simply high value objects: the spread of copper coins throughout the deposits at Songo Mnara-within houses and open spaces-suggests that they were, in fact, in common use. Rather, we argue that coins had multiple uses within Songo Mnara, as common currency, symbolic or religious items, and precious objects, depending on the context of use (Wynne-Jones and Fleisher 2012).

\section{Conclusion}

The deposit of 360 coins within the floor of a house at Songo Mnara provides important chronological and typological information on Kilwa-type coinage, as well as a rare glimpse into the complex usage of coins in a classic Swahili town. The make-up of the deposit helps to refine the final centuries of the minting and use of Kilwa coins, indicating that some types once believed to be associated with the $16^{\text {th }}$ century may now be linked to the $15^{\text {th }}$ century or earlier (Nasir ad-Dunya). The assemblage also confirms recent concerns about the use of Kilwa coins for dating, especially from post $11^{\text {th }}$ century contexts, as coins stayed in circulation over centuries-long periods. The proportion of coins found in archaeological assemblages thus seems to indicate the minting practices of individual sultans, and the residual effects of certain sultans who minted a great many coins. Finally, the retrieval of a representative assemblage of coins from the floor of a house suggests that copper coins had value that exceeded that of a simple currency. This value was made meaningful by burying it along with a string of carnelian beads, removing them from circulation and use. 


\section{List of Figures}

Figure 1: Eastern African coast and the Kilwa Archipelago

Figure 2: Plan of Songo Mnara showing House 31 and room with coin deposit

Figure 3: Coins and carnelian beads from deposit in SM017

Figure 4: Plan of SM017 showing context \#17011 and \#17012 in northwest corner of room

Figure 5: Coins likely minted from the same die: left from Mafia Island hoard, TCC 56-KM; right from Songo Mnara deposit in SM017, SF17069. The colour differences in the coins are unfortunate, but unavoidable. The corrosions were removed from TCC 56, while the SM coin has not yet been restored.

\section{List of Tables}

Table 1: Proportions of identifiable coins from the Songo Mnara deposit

Table 2: Coins from the 2011 excavations at Songo Mnara 


\section{Bibliography}

Album, S. 1999. Sylloge of Islamic Coins in the Ashmolean: Arabia and East Africa. Oxford: Ashmolean Museum Press.

Brown, H.W. 1991. Three Kilwa Gold Coins. Azania XXVI: 1-4.

Brown, H.W. 1993. Coins of East Africa: An Introductory Survey. Yarmouk Numismatics 5: 916.

Chami, F. 2006. The Archaeology of Pre-Islamic Kilwa Kisiwani (Island). In The African Archaeology Network: Research in Progress. J. Kinahan and J. Kinahan eds.: 119-150. Dar es Salaam: Dar es Salaam University Press.

Chittick, H.N. 1965. The 'Shirazi' Colonization of East Africa. Journal of African History 6: 27594.

Chittick, H.N. 1967. A coin hoard from near Kilwa. Azania 2(1):194-198.

Chittick, H.N. 1973. On the chronology and coinage of the sultan of Kilwa. Numismatic Chronicle: 192-200.

Chittick, H.N. 1974. Kilwa: an Islamic trading city on the East African coast. Nairobi and London: British Institute in Eastern Africa.

Fleisher, J. and S. Wynne-Jones. 2010. Kilwa-type coins from Songo Mnara, Tanzania: New Finds and Chronological Implications. Numismatic Chronicle: 494-506.

Freeman-Grenville, G.S.P. 1957. Coinage in east Africa before Portuguese Times. Numismatic Chronicle :151-79. 
Freeman-Grenville, G.S.P. 1958. The Chronology of the Sultans of Kilwa. Tanganyika Notes and Records 50: 85-93.

Freeman-Grenville, G.S.P. 1962. The East African Coast. Select Documents from the first to the earlier nineteenth century. Oxford: Clarendon Press.

Freeman-Grenville, G.S.P. 1963. Coins from Mogadishu, c. 1300 to c. 1700 . Numismatic Chronicle: 179-200.

Freeman-Grenville, G.S.P. 1971. Coin Finds and Their Significance for Eastern African Chronology. Numismatic Chronicle: 284-301.

Garlake, P.S. 1966. The early Islamic Architecture of the East African Coast. BIEA Memoir No. 1. London: Oxford University Press.

Horton, M.C. 1996. Shanga: The archaeology of a Muslim trading community on the coast of East Africa. Nairobi and London: British Institute in Eastern Africa.

Horton, M.C. forthcoming. Zanzibar and Pemba. BIEA Memoir No. 18. London: British Institute in Eastern Africa and Ashgate Press.

Horton, M.C. and J. Middleton, 2000. The Swahili: The Social Landscape of a Mercantile Society. Oxford: Blackwell.

Horton, M.C., W.A. Oddy and H. Brown. 1986. The Mtambwe Hoard. Azania XXI: 115-23. Middleton, J. 2003. Merchants: an essay in historiographical ethnography. Journal of the Royal Anthropological Institute 9: 509-26.

Mathew, G. 1959. Songo Mnara. Tanganyika Notes and Records 53: 154-160. 
Mitchell, H. 1970. Fakhr al-Dunya and Nasir al-Dunya: Notes on Two East African Topics. Numismatic Chronicle: 253-7.

Perkins, J. in prep. The Coins of the Swahili Coast c. 800-1500. PhD thesis, University of Bristol.

Perkins, J. 2012. A note on the return of Swahili coins. Azania 47(1):115-118.

Pradines, S. and P. Blanchard, 2005. Kilwa al-Mulûk. Premier bilan des travaux de conservationrestauration et des fouilles archéologiques dans la baie de Kilwa, Tanzanie. Annales Islamologiques 39: 25-80.

Walker, J. 1936. The History and Coinage of the Sultans of Kilwa. Numismatic Chronicle: 4381.

Walker, J. 1939. Some New Coins from Kilwa. Numismatic Chronicle: 223-7.

Wynne-Jones, S. 2013. The Public Life of the Swahili Stonehouse, 14th - 15th centuries AD. Journal of Anthropological Archaeology (online).

Wynne-Jones, S. and J.B. Fleisher. 2010. Archaeological Investigations at Songo Mnara, Tanzania, 2009. Nyame Akuma 73: 2-8.

Wynne-Jones, S. and J.B. Fleisher. 2011. Archaeological Investigations at Songo Mnara, Tanzania, 2011. Nyame Akuma 76: 3-8.

Wynne-Jones, S. and J.B. Fleisher. 2012. Coins in Context: Local Economy, Value and Practice on the East African Swahili Coast. Cambridge Archaeological Journal 22(1): 19-36. 